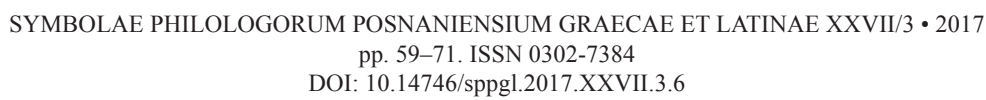

ANNA MARIA LASEK

Adam Mickiewicz University, Poznań

\title{
THE ELEMENTS OF COMEDY AND PARODY IN THE DIONYSIACA OF NONNUS
}

ABSTRACT. Lasek Anna Maria, The elements of comedy and parody in the Dionysiaca of Nonnus.

In this article the author presents the elements of comedy and parody in the Dionysiaca of Nonnus. The analysis of the passages excerpted from the Dionysiaka shows that the composition of Nonnus' poem is based on the principle of generic variety.

Keywords: Nonnus; Dionysiaka; parody; Ares; Aphrodite.

Scholars agree that literary genres have a certain momentum, and that they change. Any author within a genre develops and transforms it to create a work combining traditional genre features with new and unexpected elements. ${ }^{1}$ This way, every implementation of a genre means bringing it up to date and sets anew its boundaries. This phenomenon is particularly clearly visible in a work written by Nonnus of Panopolis in late Antiquity. As its author highlights in the proemium, this work is based on the principle of poetic variety - varietas

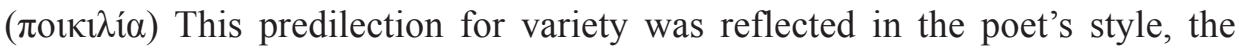
richness of synonyms appearing in the Dionysiaca; his striving for diversification in presenting characters, situations and things; and the composition of the work. ${ }^{2}$

Undoubtedly, as results from the same principle of diversity - $\pi$ oเкı $\lambda i \alpha^{3}$ the term epos is not sufficient for Dionysiaca. In the entire body of the work, one can trace elements of various genres, and even entire passages bearing their characteristics so clearly that scholars have not hesitated to identify them with idyll, epigram, etc. Many Nonnus' scholars agree that a number of fragments

\footnotetext{
${ }^{1}$ See Stanzel 1998, 143.

${ }^{2}$ Three planes of the mentioned principium variationis, were distinguished, in which this diversity is particularly visible in Nonnus: a) in style, b) in presenting characters, c) in the composition of the work. See String 1966, 33 and R. Shorrock 2001, 21: "By containing Proteus within the poem Nonnus makes an open declaration, and demonstration, of his poetic principles:

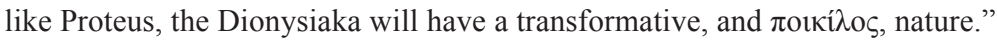

${ }^{3}$ Fauth 1981, 20.
} 
can be found in his work containing individual elements from different literary genres. $^{4}$

Although scholars ${ }^{5}$ quite soon observed the said phenomenon of fragments bearing clear traits of various literary genres appearing in the Dionysiaca, unfortunately, there are few studies discussing reference to different literary genres (e.g. tragedy, idyll or epigram) in the structure of the epos. ${ }^{6}$ Surely, the issue of final form of Nonnus' epos being influenced by many literary genres not mentioned here, particularly those whose presence in the epos is not explicitly marked, would require more detailed studies. It must be emphasised that only in recent years have there appeared statements of scholars suggesting that clear references can be found in Nonnus's epos almost to the entire Greek literary tradition (among others to tragedy, didactic poetry, philosophy, bucolic poetry, love elegy, Greek comedy or parody works ${ }^{7}$ ).

Unfortunately, the scholars would usually limit themselves to brief notes on this interesting phenomenon (Hollis, ${ }^{8}$ Auger ${ }^{9}$ ), only being content with indicating several fragments from Nonnus' epos or invoking the genres mentioned above, or parodying great masters' works.

The subject of references to comedy and the appearance of parodic elements in Dionysiaca was more broadly addressed by Italian scholars. It's worth mentioning that Daria Gigli Piccardi ${ }^{10}$ devoted an article to the phenomenon of irony ${ }^{11}$ in Nonnius, and Nicola Montenz proved that parodic elements occur in a presentation of the love of Indian leader Morrheus to maenad Chalcomede based

${ }^{4}$ Wójtowicz 1980; N. Hopkinson 1994, 2.

${ }^{5}$ Dilthey 1872 (quoted after F. Braun 1915) and F. Tissoni1998, 142.

${ }^{6}$ Lasek 2009.

${ }^{7}$ Hollis 1994, 46: "In Nonnus we must look for reminiscences of everything in classical and post-classical Greek poetry. In this respect as in many others, the Dionysiaca is a counterpart to Ovid's Metamorphoses, which, as well as epic, encompasses the genres of tragedy, comedy, didactic, philosophy, epyllion, pastoral, and love elegy.

${ }^{8}$ Hollis 1994, 46f. Let us stay with Ariadne for a moment: when she awakes from her sleep to find that Theseus has abandoned her, she tries to delude herself into thinking that he left her against his will, forcibly removed by some sailor, whom she proceeds to curse (47.357-63) [...]. The closest parallel to this passage anywhere in classical poetry is the Tenth Epode of Horace, where the poet summons all the hostile winds (note that the friendly Zephyr is the only absentee) to buffet the ship of his enemy Maevius, and asks that no friendly constellation (we should probably think of the Twins, Castor and Pollux) should give comfort and guidance (3-10) [...].The main model for the Tenth Epode is generally recognised to be a papyrus fragment of early iambic poetry which some give to Archilochus and others to Hipponax. But the curse poem was greatly elaborated, and became an established genre in its own right, during the Hellenistic period."

${ }^{9}$ Auger 2003, 415-432.

${ }^{10}$ Gigli Piccardi 2003, 14 (20): "la commedia (scil. in the Dionysiaca) manca ancora uno studio sistematico." The scholar also mentions the appearance of comedy elements in Nonnius' work in her articles: Gigli Piccardi 1985, 140ff. and D. Gigli Piccardi 1998, 66.

${ }^{11}$ Gigli Piccardi 1981, 177-188. 
on the text of Argonautica of Apollonius Rhodius. ${ }^{12}$ One cannot forget about an interesting study by Agosti ${ }^{13}$ who, though only cursorily, brought up epic works, ${ }^{14}$ proves that the author of Dionysiaca not only had a perfect knowledge of Aristophanes, ${ }^{15}$ but also drew on it in his epos. References to Aristophanes, Apollonius Rhodius, ${ }^{16}$ the Bible, ${ }^{17}$ and Homer (parody of a scene of catching Aphrodite and Ares in flagrante known from the Odyssey) in Nonnus' epos are undoubtedly parodic in nature.

What's worth mentioning here is one example of the discussed phenomenon given by Agosti. As he rightly points out, these are extremely subtle and sophisticated references, which only makes them accessible to educated people, real experts in Greek literature. ${ }^{18}$ A good example of this type of reference to Aristophanes' comedy is a scene in which unlucky-in-love Morrheus, driven by a burning and unfeasible desire, even considers killing his wife or the maenad who rejects him. Noticing his amorous torment (34.21-83), his servant Hyssacus (this name literally means female intimate parts ${ }^{19}$ ) prompts him to reveal to himself the reason of his anguish. The servant's name also suggests that the main character's feeling was not love, but lust...

Probably only Aristophanes' loyal readers could perceive here a reference to Lysistrata 1001. The word "vँ $\sigma \sigma \alpha \kappa \circ \varsigma$ " appears in the conversation between Kinesias with a Spartan herald who complains that because of Lampito women have pushed away men from this part of their bodies. ${ }^{20}$

Let us pass now on to the analysis of the mentioned Nonnus' references to Homer's poems. The first fragment in which scholars have seen humoristic, or

\footnotetext{
${ }^{12}$ Montenz 2004, 91-119.

${ }^{13}$ Agosti 2001, 219-255.

${ }^{14}$ Agosti 2001, 222.

${ }^{15}$ As it was already mentioned, Nonnus would often make reference to Aristophanes' works, both
} on the lexical and metaphorical levels; probably Attic comedy gave rise to catachreses - astonishing exchanges of word meanings - so favoured by the poet (Gigli Piccardi 1981, 140, 269). According to her, descriptions of farming activities frequent in the Dionysiaca belong here, which can be interpreted as sexual allusions in the light of the context. Reminiscences from Aristophanes' plays appear in Nonnus' epos in most unusual places. (Gigli Piccardi 1981, 21, Agosti 2001, 233)

${ }^{16}$ Books 33-35 are filled with a description of Indian leader Deriades' love for the maenad Chalcomede, which is modelled on the description of Maedea's love to Jason included in Apollonius Rhodius' Argonautica - for more on this, see Montenz 2004.

${ }^{17}$ Other scenes in which parody elements appear are those in which the author of Dionysiaca included a polemic with Christian religion. One can include here, among others, a scene of seducing Aura, virgin mother of the third Dionysus, Iacchus 48.842-847. This passage clearly refers to a prophecy of Isaiah 7:14 or the Gospel of Matthew, in which we read (Mt.1:23) that the virgin will conceive and give birth to a son. Many scholars see here a hidden polemic with the Christian doctrine - see, among others, Sinko 1954, 259, and Wójtowicz 1980, 50.

${ }^{18}$ Agosti 2004, 234.

${ }^{19}$ Z. Abramowiczówna 1965, 477; Liddell, Scott, Stuart-Jones, Mackenzie 1968, 1905.

${ }^{20}$ Ar. Lys. 1001. 
even parodic elements is in the proemium to the Dionysiaca. At the beginning of the epos, among sublime invocations of deities and numerous references to the great prototype of the Dionysian Tales and presenting an outline of the epic work, there appears unexpectedly a comparison not matching at all the other part of the proemium - Homer's poetry imitated by Nonnus is compared to a seal's skin of not very attractive smell (1.34-38). ${ }^{21}$

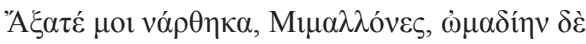

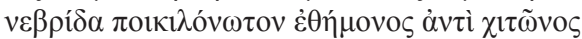

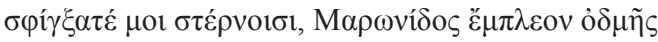

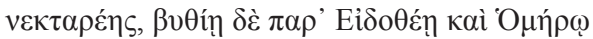

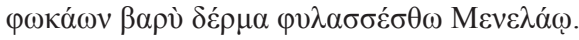

(Bring me the fennel, Mimallons! On my shoulders in place of the wonted kirtle, bind, I pray, tight over my breast a dapple-back fawnskin, full of the perfume of Maronian nectar; and let Homer and deep-sea Eidothea keep the rank skin of the seals for Menelaos. Give me the jocund tambours and the goatskins! $!^{22}$ ).

The above contrastive juxtaposition is both baffling and a source of comicality in the text under examination. However, this comparison not only makes the audience smile, but it seems that it contains a metaphorical announcement of the way Nonnus approaches the legacy of Homer. One can get an impression that the author not only wants to match the master of epos, but first of all outdo him; the reader will surely notice that this late-Antique epic poet sometimes approaches with great distance and humour the world presented in the Iliad and the Odyssey by emphasising and even exaggerating the weaknesses of the gods presented there.

A perfect example of the creative technique ${ }^{23}$ of the author of the Dionysian Tales mentioned here is a fragment from book 29 (29.325-381):

Then at Rheia's nod a deceitful vision stood by Ares, painting fantastic pictures in his sleep, and spoke thus in shadowy counterfeit shape:

328 "Sleep on Ares, sleep on hapless lover, now you lie alone in your coat of mail! But the Paphian - Hephaistos lies again in his bed and possesses Aphrodite, once yours! He has cha-

${ }^{21}$ Vian 1976, 10: "Nonnos fait mine, non sans humour, de déprécier la poésie homérique symbolisée par l'odeur nauséabonde des phoques d'Eidothéa.“

${ }^{22}$ All translation by W. H. D. Rouse (Rouse 1940). The text of the Dionysiaca is according to the text edition of Les Belles Lettres (Vian 1976 or Vian 1990).

${ }^{23}$ To facilitate deciding whether the examined fragment from Dionysian Tales bears traits that would allow classifying it a parodic text, I have specified premises on the basis of which I will classify them as parodic texts. According to a definition adopted for the purposes of this study (see Gley 2007, s.v. parody, 546), parody assumes imitation, whose objective is to recognise creative purpose of the artist. Its aim is first of all to amuse the audience. By exaggerating characteristic features, it criticises the original work. A similar role is played by deliberate combining language and style of the original with elements totally distinct from it. 
sed out the house Charis his jealous bride; Eros himself has shot reluctant Aphrodite with his arrow, and brought back the ancient wife to a second marriage to please Hephaistos his father. Indeed, Athena herself, who knows nothing of love, has persuaded great Zeus - the cunning virgin! She wants to evade Hephaistos, for she remembers the makeshift marriage on the nourishing soil, and would not nurse another son of the earth on her manlike breast, a younger brother of Erechteus now the first is dead.

340 "Awake! Go to the upland plain of the Thracian mountain, and see your Cythereia in her own familiar Lemnos. See how her swarm of attendant Loves have crowned with flowers the portals of Paphos and the buildings of Cyprus; hear the women of Byblos celebrate Aphrodite in their hymns, and the fresh love of a wedlock renewed again.

346 "Ares, you have lost your Cypris! The slow one has outrun murderous Ares the quick! Sing a hymn yourself to Aphrodite united with fiery Hephaistos! Set foot in Sicily, put your prayer, if you please, to the Cyclopes standing by their forge. They are in the secrets of Hephaistos the master craftsman, they can rival his clever work; they will invent an artifice for you and make a later imitation of your net, that you too may smother them both in galling meshes, and fasten the thief of your marriage in avenging toils, and bind limpfoot Hephaistos to Aphrodite. Then all gods of Olympos will applaud you, when you have caught the ravisher of your bed in those bonds. Awake! be the cunning schemer in your turn! Awake - attend to your stolen bride! What are the woes of Deriades to you? - But let us be silent, or Phaëthon may hear."

362 She spoke, and flew away. At once lusty Ares threw off slumber and saw early streaks of morning's light. In hot haste he leapt up, and awoke Rout and Terror to yoke his deadly quickrunning car. They obeyed their urgent father. Furious Terror set the crooktooth bit the horses' mouths, and fastened their obedient necks under the yokestrap, and fitted the neckloop on each: Ares mounted the car, and Rout took the reins and drove his father's chariot. From Libanos to Paphos he sped, and turned the hurrying car from Cythera to the land of horned Cyprus. Often, often he looked toward Lemnos; most of all he jealously watched the firebreathing forge, tracking Cypris with swift jealous foot, if perchance he could see her standing as long ago beside Hephaistos's furnace, and feared the smoke might hide Aphrodite's face with black. Then he left Lemnos and rose into the heaven, that spear in hand he might arouse battle for his bride among the Blessed, confronting Zeus and Phaëthon and Hephaistos and Athena.

The mentioned passage presents the god of war Ares ${ }^{24}$ who dozed off after hard fight with the troops of Dionysus (he fought against the god of wine at the instigation of his mother Hera, unfriendly towards Dionysus). Goddess Rhea appeared to him while he was sleeping to persuade him to leave the battlefield, and check whether Aphrodite was not cheating on him with her

\footnotetext{
${ }^{24}$ Vian 1990, 217. In a nutshell, the content of the discussed fragment of the epos is the following:

323-327 - Hera sends a deceptive dream on to Ares

Content of the dream:

328-339 Aphrodite marries Hephaestus again

340-348 Ares gets to understand his misfortune

349-358 Ares ambushes the adulterous pair

359-361 Ares leaves the battlefield

362-381 Ares sets off in search of Aphrodite.
} 
husband Hephaestus. ${ }^{25}$ Terrified with a likely loss of his mistress, Ares leaves the battlefield and has a carriage hitched up to set off in search of the alleged unfaithful one. Undoubtedly, book 8 of the Odyssey ${ }^{26}$ is a source of inspiration for the poet when composing the quoted passage. It includes a famous scene of catching in flagrante the divine pair, Aphrodite and Ares by jealous Hephaestus.

Let us pay attention to a totally distinct context in which descriptions of love adventures of god Ares and Aphrodite were placed in both eposes. In the Odyssey, these are related during a feast to amuse the listeners, and have no impact on the epos plot unfolding. In Dionysiaca, however, mentioning Ares' love adventures changes decisively the outcome of the Indian war. Let us have a closer look at the fragment of Dionysiaca describing the Aphrodite and Ares' love affair (29. 325-327):

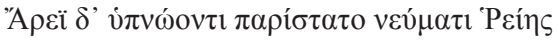

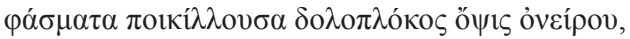

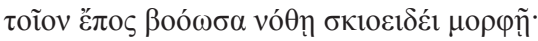

As it has already been mentioned, the examined episode begins with an intervention by the goddess Rhea, who sends a dream apparition to Ares after the night has fallen and the first day of fight has ended (29.323f). In accordance to the epic convention, the plot shifts to another level where the night - when human actions and war turmoil subside - is the time when the gods themselves can come out. ${ }^{27}$ This fragment undoubtedly refers to the Iliad, in which deceptive dreams are sometimes sent on by the gods. In Homer, the king of the gods himself, Zeus, sends a deceptive dream on to Agamemnon at night (Il. 2.1ff). The dream apparition encourages him to fight the Trojans. This fact, as it is well-known, contributed to a temporary victory by the Trojans and the defeat of the Greek troops. In the Dionysiaca, however, the dream sent by Rhea has a totally different purpose than the one in the mentioned passage of the Iliad. Here, the dream apparition is supposed to draw Ares away from the fight to make it possible for Dionysus to efficiently combat the Indian troops.

${ }^{25} \mathrm{D}$. Auger $(2003,420)$ : “De part et d'autre de cette articulation, se répondent les deux autres songes des chants XX et XXIX qui font apparaître Rhéa, d'abord une fausse Rhéa (en fait Éris déguisée), puis la vraie, qui change de forme pour égarer Arès. Cette dernière vision semble retourner comme un doigt de gant le songe divin d'incitation au combat et le vider de son sens, puisque Rhéa pousse Arès, le dieu de la guerre, à... quitter le champ de bataille, pour vérifier où se trouve Aphrodite, accusée par le fantôme de tromper le dieu avec son ancien époux Héphaïstos. Arès abandonne la guerre pour constater un adultère supposé, qui fait écho à l'épisode du chant VIII de l'Odyssée pour en inverser les rôles. Avec cet épisode ouvertement parodique, Nonnos semble donner son congé á la scène de, rêve trompeur de l'épopée: il n'y en aura plus d'autre dans le poème."

\footnotetext{
${ }^{26}$ Agosti 2004, 326.

${ }^{27}$ Compare Del Corno, Maletta, Tisson 2005, 267.
} 
The intervention of the former educator of the god of wine is so effective that only Hera will manage to restore the balance on both sides of the conflict (30.231ff.; 32.162-180).

\subsection{9-339:}

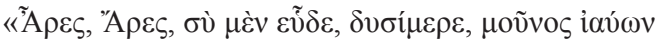

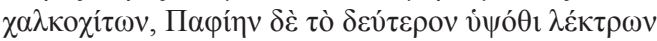

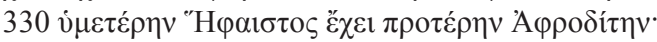

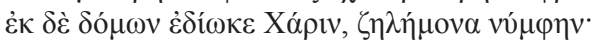

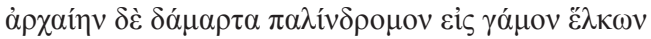

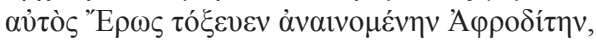

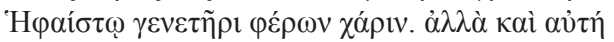

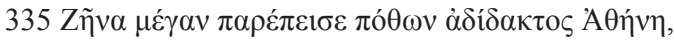

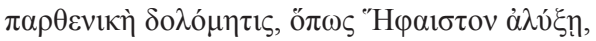

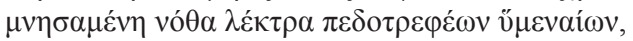

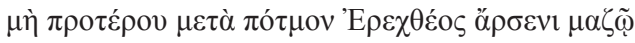

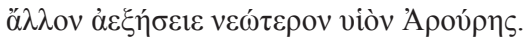

In the first verses of the dream apparition speech (29.329), there appears an apostrophe to Ares clearly invoking the Iliad $(5.31 ; 455)$. After this introduction, the apparition informs the god of Aphrodite's unfaithfulness and her return to her husband Hephaestus. Note that both in the Dionysiaca and the Odyssey (8.267ff), in the description of the love affair of the god of war with the goddess of love, the gods being cheated find out about the infidelity of their loved one from another divine person: in Dionysiaca, Aphrodite's unfaithfulness is notified to Ares by the apparition, and in the Odyssey, the love affair of Ares and Aphrodite's comes to light thanks to the god Helios. Note that this god appears as Phaethon in an analogous text by Nonnus' (29.361). As in the Odyssey, the allseeing eyes of the god of the Sun are a threat to the love affair of the god of war and the goddess of love. Subsequent verses bring a humorous and contrastive juxtaposition of pictures from the battlefield (lonely Ares wearing armour, lying on the battlefield) and marriage chamber (a married couple enjoying the delights of carnal love).

In the following verses (29.329-339), the author of the epos justifies this unfolding of events, quite unexpected for Ares, and takes this opportunity to draw attention to an oversight of his master Homer. As we remember, the master of epos provided in his works ambiguous pieces of information on who was the legitimate wife of Hephaestus: in the Iliad, this title was carried by one of the Charites (18.382-383), while in the Odyssey (8.267ff), the goddess of love is the lame god's wife. Nonnus solves this yet unresolved contradiction in a very inventive way, and, combining both versions, he suggests that Hephaestus abandoned his legitimate wife Aphrodite when he found out about her infidelity, and married one of the Charites (5.581-585). However, the newly-wed wife tormented him with scenes of jealousy. So, he finally left her, and married 
Aphrodite again assisted by Eros (29.333f). The history of the divine couple's re-marriage is for Nonnus a perfect occasion to relate a story of Hephaestus' unfulfilled love to virgin Athena (29.334-339).

\subsection{0-345:}

"E

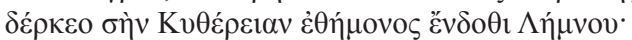

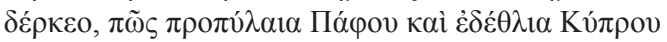

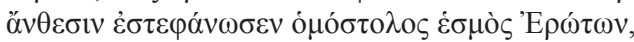

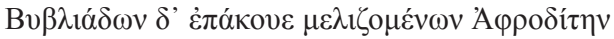

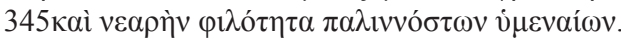

In subsequent verses of the discussed passage, we can also find, derived mostly from the Iliad (14.227-30), a catalogue of locations related to the protagonists of this special love affair - the goddess of love (Paphos, Byblos, Cyprus), Hephaestus (Lemnos) and Ares (Thrace). Verses 29.341-342f f begin with an invocation to Ares repeated twice to look at Aphrodite's re-marriage with the divine blacksmith. The discussed scene humorously invokes a fragment of the Odyssey book (8.285f), in which Ares is presented as one who is impatiently looking out for the divine blacksmith to finally leave to Lemnos. The absence of the host was to be an opportunity for the god of war to enjoy the charms of Aphrodite. The analysed scene is another example of building a certain "world upside down" by the poet of Panopolis, in accordance with the convention he adopted, in which it is the lover who is cheated, and not the legitimate husband, The poet reaches his goal by repeatedly changing the roles of characters appearing in the analysed scene (Hephaestus - he is no longer a cheated, sympathy-arousing husband, but a lover with whom Aphrodite cheats on her... lover).

\section{346-361:}

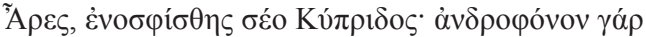

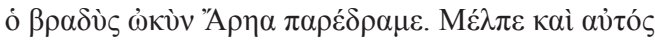

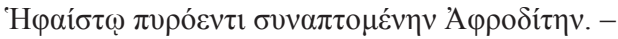

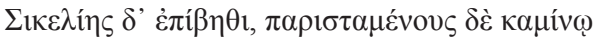

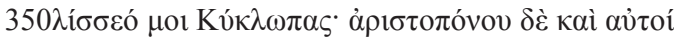

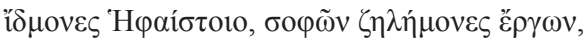

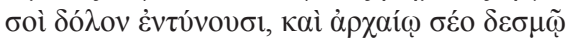

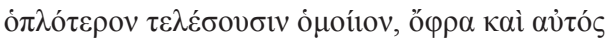

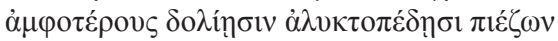

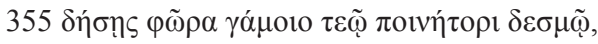

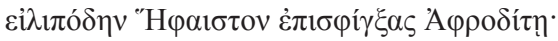

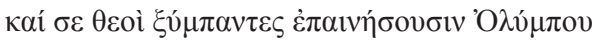

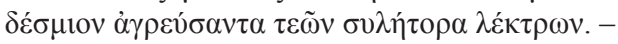

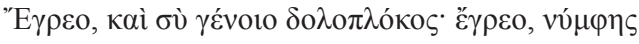

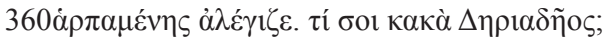

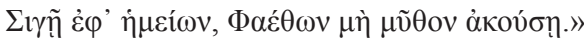


Special attention deserve verses ${ }^{28} 29.346 f$, which refer directly to the Odyssey $\left(8.329-332^{29}\right)$ repeating the contrastive juxtaposition of quick Ares (29.346f:

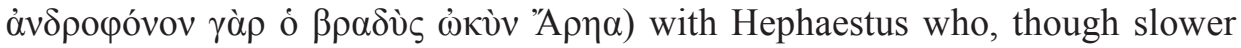
by nature (29.247: $\beta \rho \alpha \delta$ v̀s), yet he was faster than Ares in the struggle for the favours of the goddess of Paphos. This devaluating comparison of Ares with the blacksmith of Lemnos surely aims to encourage the god of war to fight for the beloved woman. It's worth adding that Ares' war competence is highlighted

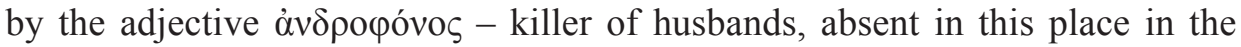
Odyssey.

Further on in Nonnus' text, we can find another element referring to the Odyssey (8.267ff) - the cheated lover, usurping the rights of husband (29.355,

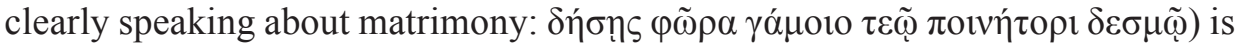
to catch in flagrante the adulterous pair in a net, and show them at the meeting of the gods. It's worth noting, however, that further on in the speech, the dream apparition presents paradoxical propositions to convince Ares to take actions against the legitimate husband, and prepare an ambush in which he found himself another day thanks to the lame blacksmith. ${ }^{30}$ The trap was to be prepared by Hephaestus' servants. This way, the god of war would surely not only expose himself to ridicule, but also doom his plan to failure in advance. For it's hard to suppose that Hephaestus' servants would help their master's enemy.

The discussed passage also presents the world upside down, in which nonmarital love is nothing shameful, on the contrary - it is a value worth fighting for. Ares behaviour is funny, as he acts like a jealous, cheated husband, although he has no right to do that. The speech of the dream apparition is completed with another appeal for Ares to wake up and fight for the beloved one. Attention is

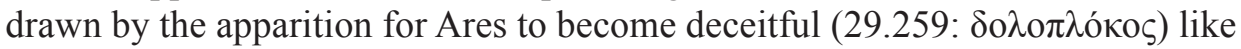
his beloved Aphrodite. ${ }^{31}$ The scene of hitching-up the carriage before setting off to fight for the mistress following the discussed appeal highlights in a humorous way the meaning of this quest to the god of war. As is well-known, this scene characteristic of the epic convention usually appears before important moments crucial for the characters. ${ }^{32}$ In Nonnus, however, it appears when Ares begins to search for his mistress who, as Ares assumes, has returned to her husband. This combination of the insignificance of the matter and epic pathos of the

\footnotetext{
${ }^{28}$ Del Corno, Maletta, Tissoni 2005, 268.

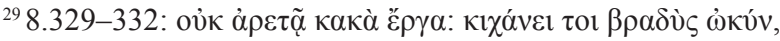

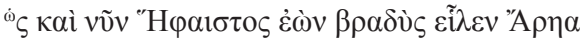

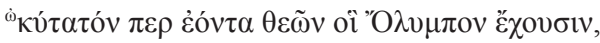

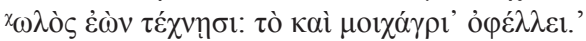

${ }^{30}$ Del Corno, Maletta, Tissoni 2005, 268.

${ }^{31}$ This adjective is a traditional epithet of Aphrodite, compare Safona, fr. 1, Lobel-Page,

${ }^{32}$ Il. 5.729-732 ; 19.392-395; Vian 1990, 218; Agosti 2004, 330.
} 1 Voigt. 
scene of hitching up the carriage is doubtless a source of comicality. A similar contrast can also be found in consecutive verse (29.260), in which two values are juxtaposed as equivalent: helping Deriades and preoccupation of the god of war with his own private matters. Further on in the story, Ares shows his meanness, as he decides to sacrifice the Indian troops good to save the jeopardised love.

\author{
29.362-381:

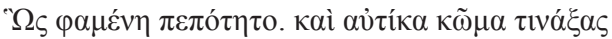

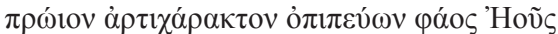

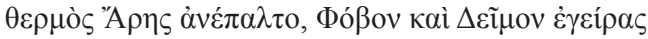

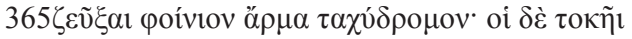

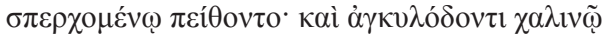

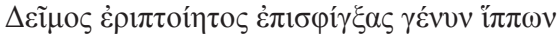

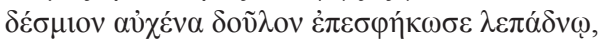

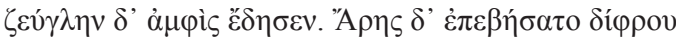

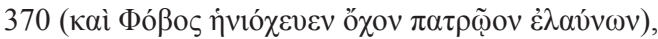

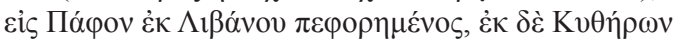

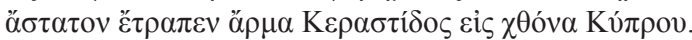

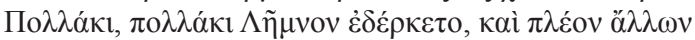

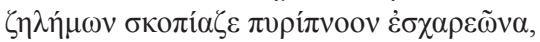

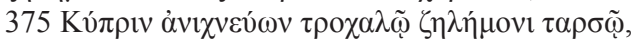

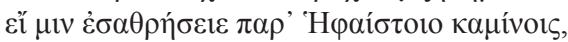

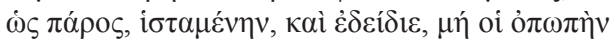

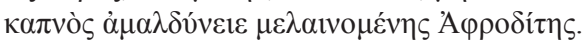

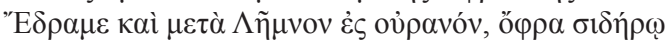

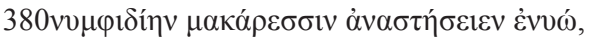

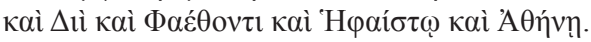

Subsequent verses describe how Ares, not having found Aphrodite in her favourite places, threatens the gods, whom he thinks are in favour of Aphrodite and Hephaestus' being together again, and intends to fight them all. Undoubtedly, his behaviour is a parody of the way cheated Hephaestus behaves as described by Homer. There, the master blacksmith calls on to Zeus to give him back a statue he gave him for his unfaithful wife, and shows it to a numerous group of gods. Ares' absurd threats of setting off against the Olympian gods make the god of war bear some traits of the soldier-braggart (Ares believes that nothing can resist his force, and intends to defeat all the gods $\left.{ }^{33}\right)$. Also, it's worth noting that the places visited by Ares to find his beloved one (29.370ff: Lemnos, Paphos, Cyprus, Lemnos) have already been mentioned earlier in the apparition speech (29.340ff).

Verses 29.377ff describing the visit of the god of war in Lemnos, where Hephaestus' forges were situated, are perhaps a humorous reference to the scene of Aphrodite's washing and perfuming herself presented at the end of

\footnotetext{
${ }^{33}$ F. Vian 1990, 354. G. Agosti 2004, 332.
} 
Demodocus' song. ${ }^{34}$ Note that in Dionysiaca the divine husband murderer is afraid that the fumes from Hephaestus' furnace will obliterate his beloved one, and he will fail to find her. It is the unusual contrast of seriousness associated with the figure of the god of war and his humorous concerns that undoubtedly renders the whole situation grotesque. ${ }^{35}$

As it was rightly pointed out by Francesco Tissoni, ${ }^{36}$ already the text of the Dionysiaca itself contains a hint that reveals the deceptive nature of Ares' dream. In the last verses of its speech (29.361ff), the dream apparition encourages Ares to keep silent so the god of the Sun does not happen to hear the plans of capturing the pair of divine lovers. Here a question arises why Phaethon should not find out about the plans for catching the couple in love, as after all this god is famous for helping cheated husbands. This discrepancy points to the deceptive nature of the dream, which could certainly be revealed to Ares by the god of the Sun. ${ }^{37}$

Note that in the discussed text one can distinguish two interrelated planes: the world of the Indian war, and the unreal world of dreams. Paradoxically, Rhea's intervention in the world of dreams produces a real effect in the Dionysian world: the god of war leaves the battlefield, thereby enabling the Dionysus' army to effectively fight the Indians. This way, the two realities intermingle, which enables the author of the epos to overstate the vices of the gods he presents. Note that the examined text has basically two audiences: internal and external: these being Ares and the reader. Each of them perceives the intertextual situation in a completely different way, and has different knowledge of the presented situation. To some extent, the reader is an external observer, and the fact that divine Ares lets himself be cheated ensures an additional humorous effect here.

The above analysis demonstrates that in the examined text the author of the Dionysiaca, although he refers to Homer, and seemingly preserves all the elements of epic poetry composes them in a way that astonishes the reader. Emphasising the human qualities of the presented gods, and their weaknesses, combined with the epic convention, provides the discussed text with clear properties of parody (bringing to mind Lucian's works ${ }^{38}$ ), such as their tendency to infidelity and extra-marital love affairs, lack of responsibility, and preferring private matters to the public good and one's own commitments. We could add that the examined fragment overstates Ares' characteristics not in keeping with his divine pedigree. The god of war, called husband murderer, is characterised by audacity, but also gullibility and credulity - like a plain mortal he believes in the dream without reservations.

\footnotetext{
${ }^{34}$ Od. 8. 364-365, this fact was noticed by Agosti; see Agosti 2004, 331.

${ }^{35} \mathrm{~F}$. Vian 1990, 218.

${ }^{36}$ Del Corno, Maletta, Tissoni 2005, 268.

${ }^{37}$ Del Corno, Maletta, Tissoni 2005, 268.

${ }^{38}$ This was noted by F. Vian 1990, 218.
} 
The phenomenon of elements referring to comedy and parody occurring in Nonnus' work presented here in brief has inclined some scholars to suppose that the author of Dionysiaca perhaps was also inspired by mock-heroic poems. In addition, it must me pointed out that the scholars have only recently paid attention to the occurrence of references to comedy and parodic elements in the Dionysiaca, and this issue requires further study. ${ }^{39}$ Although there actually exist no essential of this interesting issue, it seems that Nonnus imitated and parodied various well-known literary works. The answer to the persistent question of which of the forms of drawing on the literary tradition is more characteristic of Nonnus remains an open issue. Perhaps his tiring tendency to exaggerate and use contrasts originates in his parodic attitude to literary originals.

\section{BIBLIOGRAPHY}

\section{Primary sources}

Agosti 2004 : Nonno di Panopoli, Le Dionisiache, vol. III: Canti XXV-XXXIX. Testo greco a fronte, Ed. by Agosti, G. Rizzoli, Milano.

Gigli Piccardi 2003 : Nonno di Panopoli, Le Dionisiache, vol. I: Canti I-XII. Testo greco a fronte, Ed by Gigli Piccardi, D. 2003. Milano.

Vian 1976 : Nonnos de Panopolis, Les Dionysiaques, vol. I: Chants I-II , Ed. by Vian, F. 1976. Paris.

Rouse 1949: Nonnos. Dionysiaca, transl. Rouse, W.H.D. 1949. Mythological introduction and notes by H. J. Rose. Notes on text, criticism by L. R. Lind. Vol 1-3. London-Cambridge (Mass.): Harvard University Press. 1940.

Vian 1990, Nonnos de Panopolis, vol. IX: Chants XXV-XXIX, Ed by Vian, F.1990. Paris.

Del Corno, Maletta, Tissoni 2005 : Del Corno, D., Maletta, M., Tissoni, F. 2005. Nonno di Panopoli, Le Dionisiache, vol. 3: Canti 25-36. Introd. di D. D. C., traduzione di M.M., note di F. T., Adelphi, Milano.

\section{Secondary sources}

Abramowiczówna 1965: Stownik grecko-polski, Ed. by Abramowiczówna, Z. vol. IV, Warszawa. Agosti 2001: Agosti, G. 2001. "Late Antique Iambics and Iambikè Idéa". In A. Cávarzere, A. Aloni, A. Barchiesi (eds.), Iambic Ideas: Essays on a Poetic Tradition from Archaic Greece to the Late Roman Empire, 219-255.

Auger 2003: Auger, D. 2003. "Le monde de rêves dans les Dionysiaques de Nonnos", In D. Accorinti, P. Chuvin (eds.), Des Géants à Dionysos. Mélanges de mythologie et de poésie grecques offerts à F. Vian, , 415-432. Allessandria.

Braun 1915: Braun, F. 1915. Hymnen bei Nonnos von Panopolis. Diss. Königsberg.

Dilthey 1872: Rhein. Mus XXVII.

Fauth1981: Fauth, W. 1981. Eidos Poikilon. Zur Thematik der Metamorphose und zum Prinzip der Wandlung aus dem Gegensatz in den Dionysiaka des Nonnos von Panopolis. Göttingen.

\footnotetext{
${ }^{39}$ As was rightly noted by the investigator of dreams in Nonnus' work, D. Auger, (Auger 2003, 420ff), Ares' parodic dream is the last deceptive dream appearing in Nonnus' work. Perhaps, as the scholar suggests, the author of Dionysiaca intended to underline this way his intention to outdo the master of epos by beginning with imitation of deceptive dreams from Homer's works, and ending in their parody.
} 
Gigli Piccardi 1981: Gigli Piccardi, D. 1981. "Il Perseo nonniano. Osservazioni per uno studio dell'ironia nelle Dionisiache." Prometheus 7, 177-88.

Gigli Piccardi 1985: Gigli Piccardi, D. 1985. Metafora e poetica in Nonno di Panopoli, (Studi e testi 7). Firenze.

Gigli Piccardi 1998: Gigli Piccardi, D. 1998. "Nonno e l'Egitto (I-II).” Prometheus 24, 66.

Gley 2007: Gley, R. 2007. Brill's New Pauly, Encyclopaedia of the Ancient World-Antiquity, vol. 10, (Obl-Phe), Leiden-Boston.

Harder, Regtuit, Wakker 1998: Harder, M. A., Regtuit, R. F., Wakker, G. C. 1998. (eds.) Genre in Hellenistic Poetry, Groningen.

Hollis 1994: Hollis, A. S. "Nonnus and Hellenistic Poetry.” In Hopkinson, N. 1994. (ed.), Studies in the "Dionysiaca" of Nonnus, (PCPhS Suppl. 17), 43-62. Cambridge.

Hopkinson 1994: Hopkinson, N. 1994 (ed.), Studies in "Dionysiaka" of Nonnos, Cambridge.

Lasek 2009: Lasek, A. M. Nonnos'Spiel mit den Gattungen in den "Dionysiaka”, Poznań.

Liddell, Scott, Stuart-Jones, Mackenzie 1968: Liddell, H.G., Scott R., Stuart-Jones, H., Mackenzie, R. 1968 (eds.), A Greek-English lexicon, Oxford.

Montenz 2004: Montenz, N. 2004. "Nonno di Panopoli e Apollonio Rodio. Tecniche di riuso e parodia nei canti 33-34 dei Dionysiaca." Acme 57, 91-119.

Shorrock 2001: Shorrock, R. 2001. The Challenge of Epic. Allusive Engagement in the Dionysiaca of Nonnus. Leiden.

Sinko 1954: Sinko, T. 1954. Literatura grecka, vol. III, part 2, Wrocław.

Stanzel 1998: Stanzel, K.-H. 1998. "Mimen, Miniepen und Minijamben - Theokrit, Herondas und die Kreuzung der Gattungen.” In Harder, M.A., Regtuit, R.F., Wakker G. C., (eds.) Genre in Hellenistic Poetry, Groningen, p. 143.

String 1966: String, M. 1966 "Поькı $\lambda$ ía als Stilprinzip" In: Untersuchungen zum Stil der Dionysiaka des Nonnos von Panopolis. Diss. 34. Hamburg.

Tissoni 1998: Tissoni, F. 1998. Nonno di Panopoli, I canti di Penteo (Dionisiache 44-46). Commento, Firenze.

Wójtowicz 1980: Wójtowicz, H. 1980. Studia nad Nonnosem, Lublin.

\title{
KOMÖDIENHAFTE UND PARODISTISCHE ELEMENTE IN DEN DIONYSIAKA DES NONNOS
}

\author{
Zusammenfassung
}

Es wurde schon von einiger Zeit beobachtet, dass in Nonnos' Epos Passagen mit parodistischer Färbung zu finden sind. Die parodistischen Elemente befinden sich schon im Proemium der Dionysiaka, wo Homers Epen mit stinkenden Robbenfellen verglichen werden (1.34-38). Eine andere Szene mit parodistischen Zügen ist die Passage aus dem 29. Buch (29.325-362), in der der Traum von Ares geschildert wird. Diese Beschreibung knüpft an das 8. Buch der Odyssee an, in der die Liebesaffäre von Aphrodite und Ares dargestellt wird, und spielt sehr raffiniert mit den dort enthaltenen Motiven und Themen. Die Analyse der Fragmente, die parodistischen Charakter aufweisen, zeigt, dass die Dionysiaka nach dem Prinzip der literarischen und kompositorischen Vielfalt (varietas) gebaut wurden. 